\title{
Child Witches in Kinshasa, DRC: A Response
}

\author{
Paul M. Mpindi
}

\section{Introduction}

Let me first introduce myself, as this will explain my take on this crucial subject for the future of the body of Christ in Kinshasa (Congo), and in the rest of the body of Christ in Africa.

I was born and raised in Kinshasa in the context of a conservative church that didn't know much about spiritual warfare. Sensing God's calling over my life, I left home to attend seminary, first at an Evangelical seminary in Bangui (Central African Republic); and later at a Reformed seminary in America.

Although I am an African, my church tradition and theological training didn't prepare me correctly on how to deal with the supernatural worldview that dominates our African culture. It was only after my doctoral studies that I became aware of the existing biblical teaching and practices regarding spiritual warfare. I have been since involved in spiritual warfare training, teaching and ministry for the past 10 years (please see my French book on the subject: Cure d'âme profonde et délivrance spirituelle, published by Presses Bibliques Africaines [PBA] (2014).

Here then are a few comments about the subject of: child witches in Kinshasa (DRC) in response to the report by Priest, Ngolo and Stabell (2020).

\section{Yes, Witchcraft is Real and Children Witches are Real in Kinshasa!}

It is a commonplace to assert that witchcraft is real in Africa, and particularly in Congo. No true African will ever doubt that. The powers of darkness are real and pervade the African worldview.

The phenomenon of child witches is not recent in Africa. Always, in most African tribes, children have been bewitched early in life, because they are easy prey. Most child witches were bewitched by members of their own family. The following story comes from my personal experience with deliverance ministry.
A few years ago, while I was ministering in Kinshasa, I received a Christian couple in their forties. The man was suffering from a sudden and inexplicable blindness. While ministering to them, the couple told me that two of their young children, their 14-year-old daughter and their 10-year-old son, confessed that they are the cause of their father's blindness.

As I listened to them, I grew concerned that this Christian couple had fallen prey to spiritual falsehood. In my mind, I dismissed their explanation and asked them if they could allow me to meet these kids privately without them being present. Indeed, the following day I met the two children privately. I started by asking them if their parents put words in their mouths about them being witches. The kids said, "no". I then asked them if they were witches. They both said, "yes". I asked them how they became witches. The oldest one explained that she became a witch at age 10 or so, and she is the one who recruited her brother to become a witch as well.

I then asked them if they are the ones who made their dad go blind. They both said, "yes". I asked them why, and they said that making their dad blind was the only way they could save his life because their aunt, the person who made them witches wanted them to kill their dad, but they refused. In order to avoid being killed themselves, they had to somehow hurt their father, and they chose making him blind instead of killing him.

I ended up ministering to these two kids, first leading them to Christ, then making them renounce the devil and sorcery as well. These two kids told me so much about the inner workings of the dark world. It was impossible for these two little kids to know so much about sorcery without themselves being sorcerers. 


\section{Yes, Untrained, Overzealous, and Heretical African Pastors are the Problem!}

As argued before, child witches have always been part of the African traditional communities. But what is troubling is that untrained, overzealous, and mostly heretical African pastors are the ones pushing a negative narrative that indiscriminately labels all problem children as sorcerers. Not only do these pastors often accuse innocent children of sorcery, but they also use unbiblical deliverance practices on people who need spiritual deliverance.

Now, using child witches as a "one size fits all" answer to poverty and life crisis is one issue, but using unbiblical deliverance practices to address this phenomenon is another issue that the body of Christ in Africa must deal with urgently.

Indeed, most Western missiologists marvel at the impressive growth of Christianity in Africa. But it is my contention that actually African Christianity is not "growing", instead African Christianity is "swelling". And my fear is that it won't take long for this unhealthy strand of Christianity to burst!

\section{Yes, this Unfortunate Situation Can Be Fixed!}

My own experience as a theology professor and a deliverance minister in Africa is that most untrained and heretical Christian preachers who are destroying the church in Africa today are open to teaching. Our yearly trainings and conferences throughout the continent see thousands upon thousands of these pastors come and receive teaching with an open heart. Many of them do change.

Now the challenge is to find ways to address this crisis that would be both biblically sound and practical. Here are three avenues that we could follow that would greatly help our church leaders who minister in the area of spiritual warfare in the African context:

\section{a) Let Us Recognize the Reality of Child Witches}

One of the dangers we face as Christian leaders in Africa is of simply ignoring the reality of the crucial impact of the supernatural in the African worldview; but those who are careful students of Scriptures find a clear similarity between the biblical worldview and traditional African worldviews.

Both in biblical and in traditional Africa worldviews, there is a clear continuity between the supernatural and the natural worlds. In the Bible as well in Africa, there is but One True God, creator of the universe and mankind. Both in the Bible and in Africa, the One True God, is surrounded by a host of angels, good and bad! And these angels interact with the human community in every life situation. Indeed, the only major and decisive difference between the biblical and African worldviews lies in the nature and work of Christ, the Son of God, the only True Mediator, and the multiple human and spirit mediators found in the African worldview (see the discussion of the subject in my book, Manuel de morale chrétienne en milieu africain (2014).

When Christ replaces African ancestors as the only True Mediator between God and the community of the living and the dead, then African Christianity will gain in biblical doctrinal soundness, and ministry efficiency. Indeed, most untrained African pastors and deliverance ministers are bringing trouble and chaos in the body of Christ, because of their syncretistic approach which mixes Christ with traditional spirituality. But once the christological debate is won, and Christ becomes the only and sole Ruler and Mediator between the human community and God, real or imagined child witches will no longer fall victims to the syncretistic forces in action now.

\section{b) Let Us Put in Place Lean Teaching Systems to Train Untrained Pastors}

Because of the large number of untrained pastors and church leaders already ministering in Africa, the traditional teaching model of Bible schools and seminaries won't be enough to answer this challenge. Africa is overdue for serious electronic and online biblical and theological training platforms. These electronic and online biblical and theological training platforms have the advantage of helping African church leaders to be equipped at their own pace without having to leave their local churches.

For these electronic and online biblical and theological training tools to be effective, they have to be written taking into accounts the diverse Protestant denominations in existence in the continent. Written within the context of the larger African evangelical body of Christ, these electronic and online platforms will help unify both the theology and praxis of the African church. And this will help in eradicating not only the child witches phenomenon, but also the continuing phenomenon of traditional syncretism affecting African Christianity.

\section{References}

Mpindi, Mbunga. 2014. Cure d'âme profonde et délivrance. Presses Bibliques Africaines [PBA].

— - 2014. Manuel de morale chrétienne en milieu africain, Presses Bibliques Africaines [PBA]. 
Priest, Robert J., Abel Ngolo and Timothy Stabell. 2020. Christian Pastors and Alleged Child Witches in Kinshasa, DRC. On Knowing Humanity Journal $4(1): 1-51$.

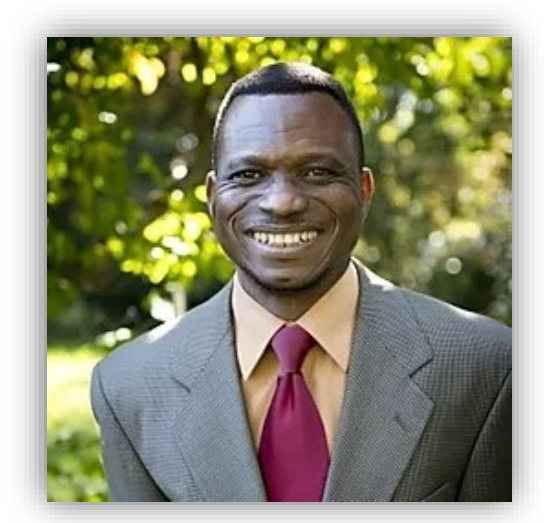

Dr. Paul Mpindi is originally from the Democratic Republic of the Congo. He is married to Charlotte Mpindi, and they have three sons. The Mpindis have been living in Grand Rapids, Michigan for the past $20+$ years. Dr. Mpindi came to the Lord at the age of fifteen, and received God's calling for ministry in his twenties. After graduating from, and teaching at Bangui Evangelical Theological Seminary (BEST) in Central African Republic, Paul and his family moved to Grand Rapids in 1993, where he completed a second Masters Degree (Th.M. in Old Testament), and a Ph.D. in Historical Theology from Calvin Theological Seminary. Dr. Mpindi is an ordained minister in the Christian Reformed Church (CRC) in North America. Both Dr. Mpindi and his wife Charlotte have been commissioned by Calvary CRC in Lowell Michigan to serve as missionaries with Mission French Africa Ministries.

Author email: mbungampindi@gmail.com 